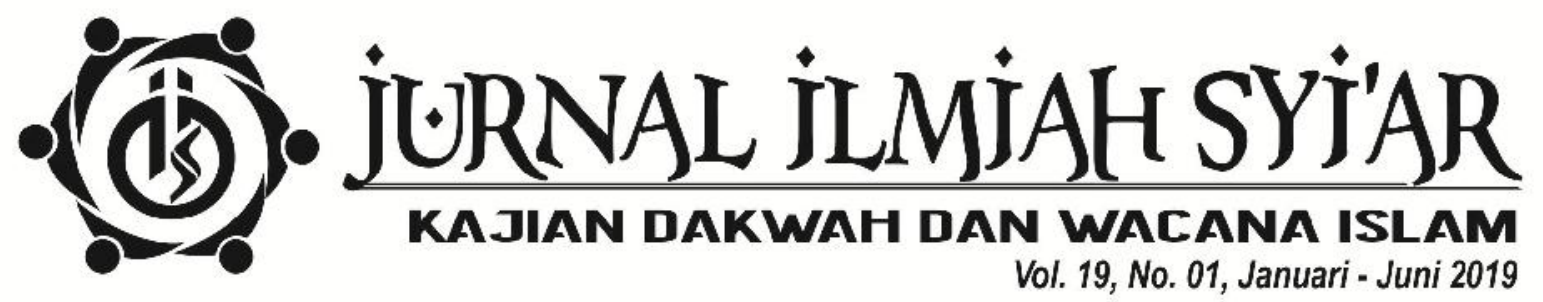




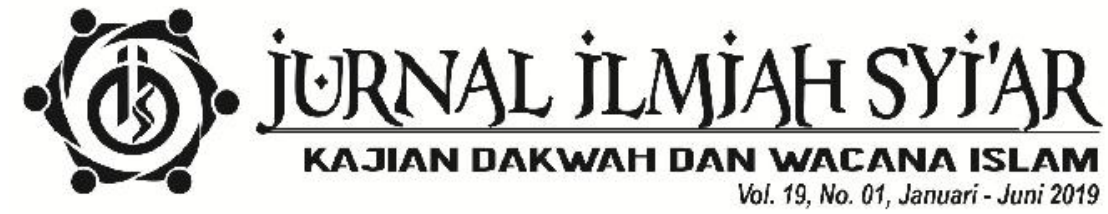

MITRA BESTARI

Khomsyahrial Romli (UIN Raden Intan Lampung)

Nelly Marhayati (IAIN Bengkulu)

Andi Dermawan (UIN Sunan Kalijaga Yogyakarta)

Bayu Mitra Aditya Kusuma (UIN Sunan Kalijaga Yogyakarta)

\section{PENANGGUNG JAWAB}

Suryani

REDAKTUR

Pebri Prandika Putra

EDITOR

Ihsan Rahmat

SEKRETARIS

Haqqi Annazili

DESAIN GRAFIS

Hymawandra

\author{
ALAMAT REDAKSI \\ Fakultas Ushuluddin, Adab, dan Dakwah \\ Institut Agama Islam Negeri Bengkulu \\ Jl. Jalan Raden Patah, Kelurahan, Pagar Dewa, Selebar, Pagar Dewa, Selebar, Kota \\ Bengkulu, Bengkulu 65144, Telp. \\ http:// ejournal.iainbengkulu.ac.id/index.php/syiar
}




\section{PENGANTAR REDAKSI}

Alhamdulillah, Jurnal Ilmiah Syi'ar, Vol. 19, No. 1 telah terbit tepat pada waktunya. Redaksi bersyukur ke hadirat Allah SWT atas seluruh karunia yang telah diberikan, baik yang terlihat ataupun kasat mata. Kemudian, shalawat beserta salam semoga tercurah bagi Nabi Muhammad SAW. Seorang rasul yang mempraktikkan berbagai metode dakwah bagi umat seluruh alam. Pada edisi ini, Jurnal Ilmiah Syi'ar (JIS) mengalami banyak pembenahan dalam rangka menuju akreditasi. Perubahan pertama datang dari ukuran jurnal cetak yang dianggap terlalu besar, sehingga redaksi memutuskan untuk menyesuaikan seukuran buku standar ISBN. Menetapkan waktu terbit dua kali dalam satu tahun, yakni edisi Januari - Juni diterbitkan pada Juni dan Juli - Desember diterbitkan pada Desember. Satu edisi berisi delapan jurnal berkualitas yang dikelola dengan sistem Open Journal System (OJS).

Pada edisi ini juga, redaksi bekerja sama dengan mitra bestari yang dinilai pakar pada salah satu fokus JIS, yaitu Komunikasi dan Penyiaran Islam, Manajemen Dakwah, Pengembangan Masyarakat Islam, Bimbingan Konseling Islam, dan Kesejahteraan Sosial. Selanjutnya, menyediakan logo khusus untuk JIS dengan tujuan mudah dikenali dan profesionalisme. Logo didesain dengan karakter tulisan 'JIS' berbentuk bulat bermakna bahwa Syi'ar Islam diperuntukkan bagi umat seluruh alam. Dakwah tidak membedakan suku, ras, agama, bangsa, dan negara. Kemudian, di luar karakter ada simbol orang yang saling bergandengan bermakna pola baru Syi'ar Islam di masa depan dengan model kolaboratif. Redaksi berpandangan bahwa kompleksitas kehidupan umat tidak mampu lagi diselesaikan dengan cara parsial atau metode dakwah perorangan.

Metode syi'ar Islam tidak mungkin dipisahkan dari sunnah Rasulullah SAW dan Khulafaur Rasyidin. Tulisan pertama mengangkat pembahasan tentang 'Manajemen Baitul Mal pada Masa Khalifah Umar Bin Khathab R.A: Sebuah Tinjauan Sejarah.' Fitmawati sebagai penulis tunggal telah banyak menulusuri proses terbentuknya baitul mal di madinah, sumber dana yang bisa menjadi pemasukan, tata cara pembagian, hingga hal teknis lainnya. Kajian ini ternyata juga mampu menjelaskan sistem ekonomi syariah di masa khalifah kedua. Tulisan kedua berupa pemikiran tentang konseling Islam berjudul 'Konselor dalam Penguatan Nilai dan Moral: Strategi Membentuk Generasi Religius' oleh Muahammad Nikman Nasir. Nasir mempertahankan argumen bahwa di era milenial, konselor membutuhkan nash-nash agama untuk membangun moral klien atau peserta didik. Agama menjadi titik tolak sebagai sumber kekuatan, agama sebagai budaya, dan agama sebagai konteks.

Ashadi Cahyadi mengisi slot ketiga dengan pembahasan 'Pembangunan dan Pemberdayaan Manusia melalui Dana Desa: Pola dari Masa Lalu hingga Sinergitas yang Rancu.' Asumsi studi ini adalah sinergitas infrastruktur diikuti dengan pemberdayaan masyarakat akan menghasilkan 
kesejahteraan yang berkelanjutan. Tetapi temuan mengatakan rasionalitas ini dinilai tidak berjalan bersamaan karena memberikan porsi yang besar untuk infrastruktur dan mengecilkan pemberdayaan manusia. Tulisan keempat milik Sifatul Aliyah dan Bayu Mitra A. Kusuma 'Tuntutan Kinerja dalam Keterancaman Kerja: Dilema Karir Penyuluh Agama Non-Pegawai Negeri Sipil.' Penulis banyak mengeksplor tentang keresahan penyuluh agama, langkah propaganda, hingga kebijaksanaan yang telah dikeluarkan pemerintah. Tulisan kelima berjudul 'Falsafah Huma Betang di Kalimantan Tengah: Sebuah Pergulatan Identitas Konselor Dayak Muslim' oleh Dody Riswanto. Dody menemukan konselor dayak muslim terbentur oleh persepsi negatif dari lingkungan sosial. Kemungkinan latar agama menjadi arus utama yang perlu dipertimbangkan untuk lingkungan Dayak yang rerata menganut agama berbeda. Penyelesaian Falsafah Huma Betang yang mengandung nilai-nilai toleransi dan saling menghargai antar pemeluk agama dinilai sebagai jembatan yang mampu mereduksi persepsi negatif.

Tulisan keenam berjudul 'Sumber Daya Manusia Koperasi Jasa Keuangan Syariah (KJKS) di Kota Padang: Dilema antara Pengelolaan dan Pemahaman Konsep.' M. Zaky Mubarak Lubis dan Netta Agusti menemukan bahwa 39\% pengelola KJKS belum memahami konsep dasar ekonomi Islam. Robeet Thadi menjadi penulis ketujuh dengan pembahasan 'Literasi Media Khalayak di Era Keberlimpahan Infomasi di Media Massa.' Ada pergeseran di era keberlimpahan informasi, yakni dari sulitnya mencari informasi menjadi sulitnya menyaring informasi. Thadi menekankan pentingnya kemampuan literasi media individu untuk melihat dan membedakan dunia nyata dan dunia yang diproduksi oleh media. Tulisan terakhir oleh Sugeng Sejati dengan judul 'Implikasi Egosentris dan Spiritual Remaja dalam Mencapai Perkembangan Identitas Diri.' Temuan utamanya adalah pengembangan identitas remaja yang egosentris dan spiritual ternyata menjadikan remaja tersebut memiliki prinsip dengan peran penting dalam kehidupan dan nilai dalam masyarakat.

Demikian catatan beberapa perubahan jurnal dan cuplikan dari isi JIS Vol. 19, No. 1. Redaksi menyadari bahwa masih terdapat berbagai kekurangan. Sehingga kritikan dan saran yang bersifat membangun sangat diharapkan demi penyempurnaan jurnal ini kedepannya. Akhirnya redaksi mengucapkan banyak terimakasih kepada berbagai pihak yang turut mendukung lahirnya edisi ini. Mulai dari para penulis yang setia merevisi berbagai kekurangan tulisan, para mitra bestari, tim redaksi yang bekerja maksimal, dan lainnya. Redaksi menunggu karya-karya terbaik penulis pada edisi berikutnya. Selamat membaca!!!

Pagar Dewa, Juni 2019 a.n TIM REDAKSI JIS Ihsan Rahmat 


\section{DAFTAR ISI}

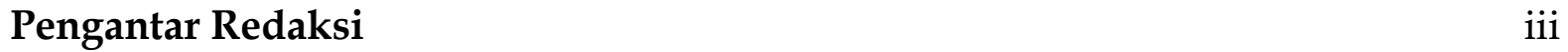

Daftar Isi

MANAJEMEN BAITUL MAL PADA MASA KHALIFAH UMAR BIN 1-29

KHATHAB R.A: SEBUAH TINJAUAN SEJARAH

Fitmawati

KONSELOR DALAM PENGUATAN NILAI DAN MORAL:

$30-42$

STRATEGI MEMBENTUK GENERASI RELIGIUS

Muahammad Nikman Nasir

PEMBANGUNAN DAN PEMBERDAYAAN MANUSIA MELALUI DANA

DESA: POLA DARI MASA LALU HINGGA SINERGITAS YANG RANCU Ashadi Cahyadi

TUNTUTAN KINERJA DALAM KETERANCAMAN KERJA: DILEMA

$55-67$

KARIR PENYULUH AGAMA NON PEGAWAI NEGERI SIPIL

Sifatul Aliyah, Bayu Mitra A. Kusuma

FALSAFAH HUMA BETANG DI KALIMANTAN TENGAH: SEBUAH

$68-76$

PERGULATAN IDENTITAS KONSELOR DAYAK MUSLIM

Dody Riswanto

SUMBER DAYA MANUSIA KOPERASI JASA KEUANGAN SYARIAH

$77-89$

(KJKS) DI KOTA PADANG: DILEMA ANTARA PENGELOLAAN

DAN PEMAHAMAN KONSEP

M. Zaky Mubarak Lubis, Netta Agusti

LITERASI MEDIA KHALAYAK DI ERA KEBERLIMPAHAN INFOMASI DI

90-102

MEDIA MASSA

Robeet Thadi

IMPLIKASI EGOSENTRIS DAN SPIRITUAL REMAJA

103-126

DALAM MENCAPAI PERKEMBANGAN IDENTITAS DIRI

Sugeng Sejati 


\title{
IMPLIKASI EGOSENTRIS DAN SPIRITUAL REMAJA DALAM MENCAPAI PERKEMBANGAN IDENTITAS DIRI
}

\author{
Sugeng Sejati \\ Fakultas Ushuluddin, Adab, dan Dakwah \\ Institut Agama Islam Negeri Bengkulu
}

Korespodensi dengan penulis:

Sugeng Sejati, Telp: 08136838 9000;

E-mail: sugengcurup@gmail.com

\section{Keywords: \\ Adolescence, egocentric, spiritual development, self identity}

\section{Kata kunci:}

Remaja, egosentris, pengembangan spiritual, identitas diri

\begin{abstract}
Adolescence is a period of development that is very important in the dynamics of life because at this time adolescents have a tendency known as Identity Versus Identity Confusion which is the main task of adolescents in achieving a development of self-identity. In fact, at this time, many adolescents have difficulties in recognizing their own identities, what their potential is and where they are going, where it becomes a very urgent problem for adolescents. While for the spiritual development of adolescents, it cannot be separated from the development of the personality as a whole, meaning that one's attitude and spiritual beliefs in his life are none other than his personal role models that grow and develop from birth especially since in the womb. The focus of this paper is the egocentric and spiritual implications of adolescents in achieving the development of self-identity. This paper is carried out through library research techniques. The conclusions of this paper normatively produce an Egocentric and Spiritual Implication of Youth in achieving the development of self-identity which makes the next person into a unique and principled person with an important role in life and value in society.
\end{abstract}

\begin{abstract}
Abstrak
Masa remaja adalah masa perkembangan yang sangat penting dalam dinamika kehidupan karena saat ini remaja memiliki kecenderungan yang dikenal dengan Identity Versus Identity Confusion yang merupakan tugas utama remaja dalam mencapai perkembangan identitas diri. Bahkan, saat ini, banyak remaja mengalami kesulitan dalam mengenali identitas mereka sendiri, apa potensi mereka dan ke mana mereka pergi, di mana itu menjadi masalah yang sangat mendesak bagi remaja. Sedangkan untuk perkembangan spiritual remaja, tidak lepas dari perkembangan kepribadian secara keseluruhan, artinya sikap dan keyakinan spiritual seseorang dalam hidupnya tidak lain adalah teladan pribadinya yang tumbuh dan berkembang sejak lahir terutama sejak di masa lalu. rahim. Fokus dari makalah ini adalah implikasi egosentris dan spiritual remaja
\end{abstract}


dalam mencapai pengembangan identitas diri. Makalah ini dilakukan melalui teknik penelitian perpustakaan. Kesimpulan dari makalah ini secara normatif menghasilkan Implikasi Remaja Egosentris dan Spiritual dalam mencapai pengembangan identitas diri yang membuat orang berikutnya menjadi orang yang unik dan berprinsip dengan peran penting dalam kehidupan dan nilai dalam masyarakat.

\section{PENDAHULUAN}

Remaja adalah bagian dari aset negara yang harus dibina dan dibimbing untuk pada akhirnya menjadi tonggak perubahan bangsa yang lebih baik di hari depan. Remaja juga merupakan salah satu proses dari perkembangan makhluk hidup, yang dimiliki oleh manusia yang pada akhirnya akan kembali pada proses kematian. Namun, banyak masalah yang bisa dialami oleh seseorang untuk memasuki masa remajanya.

Banyak perubahan-perubahan tingkah laku seseorang dalam memasuki masa remaja, termasuk perubahan yang terjadi dalam segi fisik, psikis, dan sosial, selain itu ada hal-hal lain yang akan dialami individu ketika menginjak usia remaja seperti masalah penyesuaian diri dan pergaulan bebas / tanpa batas seperti mengkonsumsi obat-obatan terlarang, sikap arogan dengan menjadikan terminologi "babe gue" sebagai senjata, suka berhura-hura, chatting atau facebook yang sangat trend saat ini, bergerombol, memberontak pada orang tua misalnya tidak menghiraukan nasehat orang tua serta menggangap dirinya benar dan tidak perlu dinasehati karena dia merasa sudah dewasa, keinginan untuk putus sekolah, seks bebas, terlebih lagi akan hal perkembangan seksual pada diri remaja, yang mengakibatkan tersebarnya virus human immune deficiency (HIV) dan acquired immune devficienncy syidrome (AIDS) yang dalam jangka panjang menimbulkan berbagai kerugian bahkan kematian, dan juga penyebab terjadinya Married By Accident (MBA) yang sering disebut dengan pernikahan dini.

“Fenomena yang mengerikan itu ternyata banyak terjadi pada kalangan remaja. Mengapa remaja? Secara psikologis masa remaja merupakan suatu masa dimana individu dalam proses pertumbuhan (terutama fisik) telah mencapai kematangan. Periode ini menunjukan suatu masa kehidupan dimana kita sulit untuk memandang remaja itu sebagai anak-anak, namun juga sebagai orang dewasa. Sehingga masa ini rentan karena selalu berorientasi pada popularitas secara menggila dan instan." 1

Menurut penulis dari penjelasan di atas remaja merupakan suatu proses perkembangan yang sangat rentan yang membuat diri remaja serba ingin tahu atau serba ingin mencoba halhal yang baru. Sehingga pada kondisi perkembangan yang seperti ini remaja sering sekali mengedepankan egosentrisnya. Artinya remaja merasa dirinya tidak perlu dinasehati karena

${ }^{1}$ Al Mighwar, Psikologi Remaja, (Bandung: Pustaka Setia, 2006), hal. 6. 
sudah merasa dewasa. Piaget dalam Hurlock, secara psikologis masa remaja adalah usia dimana individu berintergrasi dengan masyarakat dewasa, usia dimana anak tidak lagi merasa bahwa dirinya berada di bawah tingkat orang yang lebih tua melainkan merasa sama, atau paling tidak sejajar. ${ }^{2}$ Mereka hidup bersama orang dewasa. Dalam masyarakat orang dewasa mereka harus menyesuaikan diri dengan kehidupan, dimana pembatasan-pembatasan dan peraturan yang berlaku sering dirasakan remaja sebagai suatu peraturan yang sangat berat.

Bagi kebanyakan remaja, periode ini merupakan periode yang amat kritis. Artinya, jika remaja mampu mengatasi berbagai tuntutan yang dihadapinya secara integratif, ia akan menemukan jati dirinya. Sebaliknya bila gagal, ia akan berada pada krisis identitas yang berkepanjangan. Dalam hal ini Erikson mengemukakan bahwa tugas utama masa remaja adalah memecahkan "krisis" yang mana untuk menjadi orang dewasa yang unik dengan pemahaman akan diri yang utuh dan memahami peran dan nilai dalam masyarakat. ${ }^{3}$

Pada masa remaja bukan berarti seorang anak terlepas sama sekali dari ciri-ciri khas yang dimiliki pada masa sebelumnya, dalam pengertian bahwa ia akan mudah bunuh diri dan akan mudah putus asa jika kehendaknya terhalangi. Dalam gambaran umum, Umar Hasyim melukiskan sebagai berikut:

“Masa ini biasa dikatakan sebagai masa transisi, dan ini biasa merupakan masa yang berbahaya baginya, sebab ia mengalami hidup di dua alam, yakni antara alam khayalan dan alam kenyataan dimana banyak ditemukan gejola jiwa dan fisik. Transisi merupakan perpindahan alam khayalan ke alam nyata, yang mana banyak kaum remaja berkhayal bahwa dirinya merupakan seorang super hero dalam segala hal.... Gejolak emosinal yang tak terkendali akan membawanya ke alam khayal yang nyatanya tidak. Di sinilah banyak pemuda menjadi nakal karena ingin membutikan bahwa dirinya telah menjadi dewasa, pada hal sebenarnya belum apa-apa, karena kedewaasan tidak hanya pada fisik saja tetapi meliputi keseluruhan mental dan kejiwaannya."4

Pada masa remaja seorang anak bukan hanya mengalami ketidakstabilan perasaan dan emosi, dalam waktu bersamaan mereka mengalami krisis. Pada masa krisis ini seorang anak berhadapan dengan persoalan apakah dirinya mampu memecahkan masalahnya sendiri atau tidak. Jika mampu memecahkan masalah dengan baik, maka akan mampu pula untuk menghadapi masalah selanjutnya, hingga dewasa. Jika dirinya tidak mampu memecahkan masalahnya dalam masa ini, maka ia akan menjadi orang dewasa yang senantiasa menggantungkan diri kepada orang lain ${ }^{5}$.

${ }^{2}$ Hurlock, Psikologi Perkembangan, (Jakarta: Erlangga, 1992), hal. 206.

${ }^{3}$ Papa Lia, Human Development, (Jakarta, 2008), hal. 587.

4 Sudarsono, Etika Islam Tentang Kenakalan Remaja, (Jakarta: Rineka Cipta, 1989), hal. 14.

5 Ibid., hal. 15. 
Erikson berpendapat bahwa krisis utama yang sering terjadi pada masa ini adalah krisis identitas yang pengaruhnya paling besar terhadap perkembangan individu masa dewasa. Krisis identitas ini terjadi karena pada remaja kebanyakan terjadi konflik yang berhubungan dengan perkembangan identitas pribadi. Pada masa ini para remaja berjuang untuk menentukan siapa diri mereka itu sebenarnya, kemana mereka akan mengarahkan hidupnya, dan bagaimana mereka dapat mencapai arah hidup yang telah ditetapkan. ${ }^{6}$

Dengan demikian menurut penulis, egosentris merupakan suatu perhatian yang amat berlebihan terhadap diri sendiri sehingga individu merasa bahwa dirinya adalah seorang yang penting dan menjadi tidak peduli dengan dunia luar dirinya. Artinya remaja mulai berpikir menginterpretasikan kepribadiannya dan memantau dunia sosial mereka dengan cara-cara unik. Dari pendapat di atas, masa remaja adalah masa yang paling menentukan, karena pada masa itulah remaja cenderung lebih suka menyimpang dari aturan-aturan yang sebenarnya. Seandainya mereka tidak ditanamkan hal-hal yang bersifat spiritual atau agama sejak dini, maka kecenderungan untuk menyimpang akan menjadi kenyataan. Seorang remaja yang tidak dibekali agama sebagai pondasi dalam mengarungi kehidupan ini, dapat dipastikan dia tidak akan mampu melewati masa dewasa secara sempurna.

Perkembangan jiwa keagamaan pada remaja merupakan suatu hal yang sangat penting diperhatikan, mengingat pada masa remaja mulai terjadinya tahap perkembangan agama yang merupakan salah satu kebutuhan remaja akan agama. Dimana sebelumnya penulis telah menguraikan bahwa remaja secara fisik telah mengalami pertumbuhan yang pesat, dan sudah menyamai orang dewasa. Namun pesatnya pertumbuhan itu belum diimbangi setara oleh perkembangan psikologisnya. Kondisi seperti ini menyebabkan remaja mengalami kelabilan. Artinya remaja secara penampilan memang dewasa akan tetapi psikologis belum. Ketidakseimbangan ini menjadikan remaja menempatkan remaja dalam suasana kehidupan batin terombang-ambing. Untuk mengatasi kemelut batin itu, maka seyogyanya mereka memerlukan bimbingan dan pengarahan. Para remaja membutuhkan tokoh pelindung yang mampu diajak berdialog dan berbagi rasa. Selain itu, mereka pun mengharapkan adanya pegangan hidup sebagai tempat bergantung.

Dalam upaya mengatasi kegalauan batin ini, para remaja cenderung untuk bergabung dalam teman sebaya, untuk saling berbagi rasa dan pengalaman. Selain itu, kebutuhan remaja akan sosok pelindung mendorong mereka untuk memilih sosok idola. Kemudian untuk memenuhi kebutuhan emosionalnya, maka para remaja juga sudah menyenangi nilai-nilai agama dapat diperankan sebagai bimbingan rohaniyah. Menurut W. Starbuck perkembangan

${ }^{6}$ Ibid., hal. 72. 
jasmaniah dan rohaniah yang terjadi pada remaja turut mempengaruhi perkembangan agamanya. Dengan pengertian bahwa penghayatan terhadap ajaran agama dan tindak keagamaan yang tampak pada para remaja banyak berkaitan dengan faktor perkembangan jasmaniah dan rohaniah mereka. Perkembangan itu antara lain adalah pertumbuhan pikiran mental, perkembangan, perkembangan sosial, perkembangan moral, sikap dan minat.7 Berdasarkan latar belakang yang telah disampaikan di atas inilah maka penulis tertarik sekali untuk mengkaji bagaimana egosentris dan spiritual remaja dalam mencapai identitas diri, sehingga nantinya remaja akan tumbuh kembang menjadi manusia dewasa yang bahagia sesuai dengan nilai-nilai agama.

\section{METODE}

Metode Penulisan yang digunakan adalah kualitatif melalui kepustakaan (Library research) yaitu suatu penulisan terhadap beberapa literatur baik berupa buku, majalah, bulletin, surat kabar, internet, hasil seminar, dan sumber lainnya yang berhubungan dengan masalah yang dirumuskan. ${ }^{8}$ Jadi penulis disini akan melaksanakan serangkaian kegiatan pengumpulan, mengelola dan menganalisis data yang diambil dari literatur-literatur tertulis yang saling berkaitan, sehingga jelas bagaimana egosentris dan spiritual remaja dalam mencapai perkembangan indetitas diri. Sedangkan Teknik Analisis Data menggunakan metode Deduktif, Metode Induktif, Metode Komparatif. ${ }^{9}$

\section{HASIL DAN PEMBAHASAN}

\section{Perkembangan Identitas Diri Remaja}

Masa remaja merupakan masa peralihan dari masa kanak-kanak menuju masa dewasa, sehingga banyak perubahan dan minat yang diinginkan remaja. Hal itu adalah wajar karena sebagai sarana untuk menuju kedewasaan. Dalam hal ini kita juga perlu melihat bahwa kehidupan remaja dipengaruhi oleh berbagai hal seperti latar belakang pendidikan dan pengalaman, perubahan sosial pada masa remaja, minat remaja terhadap rekreasi, minat sosial remaja, minat pada simbol status, perubahan moralitas, perubahan kematangan fungsi alat seksual, kematangan emosi dan perubahan kepribadian dan masih banyak lagi hal-hal yang mempengaruhinya. Masa ini juga merupakan suatu tahapan yang terpenting dalam suatu kehidupan, yang dimulai pada masa puber dan berakhir pada usia 18 atau 21 tahun. Masa Remaja (adolescence) ditandai adanya kecenderungan identitan versus kebingungan identitas

\footnotetext{
7 Ibid., hal. 72.

${ }^{8}$ Kartini Kartono, Pengantar Metodelogi Riset Sosial, (Bandung: Mandar Maju, 1996), hal. 6.

${ }_{9}^{9}$ Nazir Mohamad, Metode Penelitian, (Jakarta: Chalia Indonesia, 1988), hal. 202.
} 
(Identity versus Identity Confusion) yang merupakan suatu tugas utama pada diri remaja yaitu dalam menghadapi Identity - Identity Confusion itu sendiri.

Identity - Identity Confusion merupakan suatu penentu siklus pertumbuhan dan perkembangan seseorang selanjutnya. Semua proses ini tujuannya adalah pencapaian identitas diri yaitu untuk menjadikan seorang yang unik dan berprinsip dengan peran yang penting dalam hidup serta bernilai di masyarakat. Sebagai persiapan ke arah kedewasaan yang didukung pula oleh kemampuan dan kecakapan-kecakapan yang dimilikinya, setiap remaja berusaha untuk membentuk dan memperlihatkan identitas diri serta ciri-ciri yang khas dari dirinya. Dorongan untuk membentuk dan memperlihatkan identitas diri ini, pada para remaja sering sekali sangat ekstrim dan berlebihan, sehingga tidak jarang dipandang oleh lingkungannya sebagai penyimpangan atau kenakalan. Dorongan pembentukan identitas diri yang kuat di satu pihak, sering diimbangi oleh rasa setia kawan dan toleransi yang besar terhadap kelompok sebayanya. Mereka mengadakan pembagian peran diantara kelompok sebaya, dan seringkali mereka sangat patuh terhadap peran yang diberikan kepada masingmasing anggotanya.

Dalam mencapai suatu perkembangan identitas diri, remaja selalu mengedepankan sifat egosentrisnya dalam perwujudan identitas diri mereka dengan melakukan suatu tindakan yang cenderung mengarah kepada kepentingan terhadap diri-sendiri dan keasikan terhadap diri sendiri dan cara untuk memandang pada hal-hal yang diterimanya baik hal-hal yang positif maupun hal-hal yang negatif yang didapatkannya dari lingkunganya. Apabila yang diterima individu itu cendrung positif maka perkembangan egonya akan baik, namun apabila yang diterimanya bersifat negatif, maka akan menganggu perkembangan ego individu untuk menjadi yang diinginkan.

Perwujudan itu dilakukan oleh seorang remaja tidak lain karena mereka ingin mencari identitas diri, dan hal ini merupakan suatu proses pertumbuhan dan perkembangan yang harus dilewati oleh remaja. Sesuai dengan pendapat yang dikemukakan oleh Erikson bahwa ada tugas utama pada masa remaja yaitu memecahkan suatu "krisis". Krisis ini dikenal dengan Identitas versus Kebingungan Identitas (Identitas versus Kebingungan Peran). Pemecahan krisis ini bertujuan untuk dapat menjadi orang dewasa yang unik dengan pemahaman akan diri yang utuh dan memahami peran nilai dalam masyarakat. Dalam hal ini juga Erikson melihat bahwa ada bahaya utama pada tahap perkembangan ini yang dapat memperlambat pencapaian kedewasaan psikologis. Artinya bahwa remaja pada tahap ini mengalami suatu kebingungan dengan mudur kemasa kanak-kanak yang terkadang terlibat secara impulsif kedalam serangkaian kegiatan yang buruk. Sesuai yang dikemukakan oleh Sanstrock: 
Menyatakan bahwa remaja memiliki kemampuan berfikir secara abstrak, ini kemudian menyatu dengan pengalaman sosial, sehingga pada gilirannya menghasilkan suatu perubahan besar dalam cara-cara remaja memahami diri mereka sendiri dan orang lain. Salah satu bagian terpenting dari perubahan perkembangan aspek kognisi sosial remaja ini adalah diistilahkan oleh psikolog David Elkin dengan egosentris yakni kecenderungan remaja untuk menerima dunia (dan dirinya sendiri) dari perspektifnya mereka sendiri. Dalam hal ini, remaja mulai mengembangkan suatu gaya pemikiran egosentris, dimana mereka lebih memikirkan tentang dirinya sendiri dan seolah-olah memandang dirinya dari atas. ${ }^{10}$

Adapun kegiatan-kegiatan yang mengedepankan sifat egosentris remaja menurut menurut penulis dikelompokan dalam dua bentuk pemikiran sosial yaitu Penonton Khayalan dan Dongeng Pribadi. Ini perkuat oleh Erikson yang menyatakan dalam diri remaja terdapat terjadi proses pemikiran soial yang disitilakan oleh erikson ialah Penonton khayalan (imaginary audience) dan Dongeng pribadi (the personal fable). ${ }^{11}$

\section{Penonton Khayalan (Imaginary Audience)}

Sifat Penonton Khayalan (Imaginary Audience) yang dimaksud adalah suatu keyakinan remaja bahwaorang lain memperhatikan dirinya sebagaimana halnya ia memperhatikan dirinya sendiri. Perilaku menarik perhatian, umum terjadi pada masa remaja, mencerminkan egosentris dan keinginan tampil di atas pangung, diperhatikan dan dilihat. Mereka menganggap semua mata terpaku pada penampilannya, ia mengaggap dirinya sebagai seorang aktor dan semua orang lain adalah penonton. Sifat egosentris penonton khayalan yang terdapat pada remaja itu dimunculkan melalui suatu sifat yang berpengaruh terhadap identitas diri. Adapun pribadi yang ditampilkan menurut penulis adalah sebagai berikut:

a. Diri remaja yang suka Berdebat dan Memberontak

Sifat egosentris suka berdebat ini merupakan suatu sikap remaja yang dilakukan karena ingin memperoleh suatu kepuasan atas kebutuhan agresifnya, dimana tujuannya adalah menghindari penolakan orang lain dan agar dapat diterima oleh masyarakat. Perlu kita ketahui juga bahwa ini bukan merupakan hal yang negatif karena sesuai dengan pendapat yang dikemukan oleh Erikson sebelumnya, sifat ini merupakan suatu sifat yang akan muncul pada tahap perkembangan diri remaja yang tidak lain tujuannya adalah mencapai suatu perkembangan identitas diri. Jadi sikap remaja yang pemberontak atau menentang di anggap sebagai fenomena positif. Sama dengan pendapat yang dikemukakan oleh Hasyimi yang menyebutkan kemungkinan untuk mengobati fenomena atau karakteristik perilaku ini dengan

10 Desmita, Psikologi Perkembangan, (Bandung: Rosdakarya, 2009), hal. 205.

11 Sastrok, Jhon W. Perkembangan Anak Edisi 7 Jilid 2. (Jakarta: Erlangga, 2011) hal.12 
cara membangun kehidupan kooperatif dengan remaja, membimbingnya merealisasikan jati dirinya, mengakui tingkat pertumbuhannya yang dijalaninya, serta berusaha menciptakan iklim saling mempercayai antara dia dan komunitas orang-orang dewasa.

Dari pemaparan yang dikemukan di atas, jelaslah bahwa pemberontakan remaja tidak bisa diobati dengan pemberontakan dari pihak-pihak orang dewasa agar remaja tidak membalas dengan pemberontakan pula, secara terang-terangan ataupun tersembunyi. Pembangkangan tidak selalu dihadapi dengan kekerasan, melainkan harus dengan ketenangan, keseimbangan emosional, dan pengarahan yang bijaksana yang membuat remaja merasa bahwa dirinya dihargai, bahwa pendidikan dan pengarahannya adalah saudara karib yang tulus.

b. Remaja yang Mengkritik dan Ingin Memperbaiki

Sifat egosentris ini merupakan suatu sikap yang juga ada pada diri pribadi remaja, dimana kita sering melihat bahwa remaja sering sekali mencari kesalahan orang lain dan cendrung mengkritik tingkah laku orang lain. Dia menganggap kritikan sebagai suatu yang negatif dan akan pula berdampak positif apabila sesuai dengan apa yang diterimanya. Dan perlu kita ketahui bahwa kritikan yang disampaikan remaja itu merupakan suatu pertanda bahwa kita dihadapkan pada individu yang pribadinya seimbang, moderat, dan dapat mengungkapkan catatan-catatan yang ia temukan dari perilaku yang ditampilkan orang lain. Penjelasan ini diatas di perkuat oleh Umar Hasyim yang melukiskan bahwa:

Masa ini biasa dikatakan sebagai masa transisi, dan ini biasa merupakan masa yang berbahaya baginya, sebab ia mengalami hidup di dua alam, yakni antara alam khayalan dan alam kenyataan dimana banyak ditemukan gejola jiwa dan fisik. Transisi merupakan perpindahan alam khayalan ke alam nyata, yang mana banyak kaum remaja berkhayal bahwa dirinya merupakan seorang super hero dalam segala hal....

Gejolak emosinal yang tak terkendali akan membawanya ke alam khayal yang nyatanya tidak. Di sinilah banyak pemuda menjadi nakal karena ingin membutikan bahwa dirinya telah menjadi dewasa, pada hal sebenarnya belum apa-apa, karena kedewaasan tidak hanya pada fisik saja tetapi meliputi keseluruhan mental dan kejiwaannya. ${ }^{12}$

Dengan demikian tindakan remaja mengkritik apa yang ia lihat pada diri orang lain, secara tidak langsung merupakan proses mencapai perkembangan identitas diri pada diri pribadi remaja sehingga pola pikir remaja terbentuk dengan kritikan tersebut.

c. Remaja yang Melawan Otoritas

Menurut penulis melawan otoritas ini merupakan suatu sifat yang juga terjadi pada remaja, dimana ini merupakan ciri khas perilaku remaja yaitu keinginan untuk melawan

12 Sudarsono, Etika Islam Tentang Kenakalan Remaja, (Jakarta: Rineka Cipta, 1989), hal. 14. 
kekuasaan. Biasanya melawan otoritas ini terjadi karena adanya suatu lingkungan yang mepengaruhi untuk mendorong bertindak misalnya adanya suatu keinginan remaja merindukan untuk mendapati dirinya berada di dunia yang lain seperti di luar lingkungan rumah, dunia yang penuh sahabat, dunia yang penuh kebebasan yang bebas dari ketergantungan anak kecil, ketika beliau mendambakan hal tersebut dia melihat orang tua dan para guru sebagai penghalang besar untuk merealisasikan impiannya. Sehingga inilah yang sering kita temui akibatnya ketika Egosentris remaja tidak terwujudkan banyak remaja yang lari dari rumah, protes, marah dan mengancam serta kadang meninggalkan keluarga.

Hal ini sesuai yang telah dikemukakan oleh Rollo May satu-satunya psikologi eksitensial yang membicarakan "Tahap-tahap perkembangan" beliau menyatakan bahwa pada tahap remaja terdapat tahap pemberontakan yaitu tahap dimana ego atau kesadaran diri anak-anak dan remaja mengalami perkembangan ke arah perlawanan terhadap orang dewasa ${ }^{13}$. Dengan demikian perkembangan dari sikap "tidak" anak-anak menjadi sikap "sekali tidak, tetap tidak" pada remaja. Peribadi pemberontak menginginkan kebebasan tanpa memahami apa tanggung jawab yang ada di balik kebebasan tersebut. Para remaja ingin menghabiskan waktu mereka dengan melakukan apa yang mereka inginkan, namun masih berharap uang jajan dari orang tua dan akan menuntut kalau mereka tidak diberi jatah.

\section{d. Setia terhadap Teman Sebaya}

Penulis menemukan kesetiaan terhadap teman sebaya ini merupakan suatu sifat egosentris yang terjadi pada diri remaja karena ini kaitannya dengan perkembangan identitas diri remaja yang diterima dalam kelompok teman sebayanya. Kelompok sebaya ini yang kadang kala bagi kalangan orang tua sangat mengkhawatirkan karena orang tua sangat khawatir kalau anaknya terjerumus kepada kelompok yang yang menyimpang, banyak persepsi orang tua ketika anak sering mengelompok pastilah melakukan perbuatan negatif padahal disini pengelompokan ini merupakan suatu kebutuhan remaja yang akan membentuk identitas pribadinya. Mengapa? Karena di sini berupaya keras untuk bergabung dengan mereka, dan berjuang untuk mengokohkan kedudukannya serta mengadopsi nilai-nilai perilaku yang dipegang oleh kelompoknya dengan sepenuh jiwa, perasaan, dan kesetiaanya.

Penjelasan yang penulis kemukkan di atas itu diperkuat oleh Erikson yang menyatakan bahwa apabila masyarakat tidak mengakui keberadaan remaja, masyarakat tidak mengakui keanggotaan remaja pada dunia orang dewasa dan masyarakat tidak mengetahui kebutuhan remaja akan identitasnya merupakan hal yang menyulitkan bagi remaja ${ }^{14}$.Tidak heran kalau

${ }^{13}$ George Boeree, Personality Theories, (Jokjakarta:Prismasophie, 2008), hal. 406

14 Syamsyu Yusup, Teori Keperibadian, (Bandung: Rosdakarya, 2008). hal. 109 
sering kita lihat remaja membiarkan dirinya melebur pada kelompoknya, terutama pada kelompok yang biasanya yang ingin sekali menyediakan secara jelas kepada identitas remaja.

Dengan demikian dari ungkapan diatas terlihat jelas bahwa pada diri remaja terdapat suatu imflusif kebutuhan harus dipenuhi karena dengan adanya suatu keinginan yang terpenuhi oleh remaja maka secara tidak langsung akan terbentuklah identitasnya yang sesuai dengan kontek sosial.

\section{Dongeng Pribadi (The Personal Fable)}

Dongeng Pribadi (The Personal Fable) ialah bagian dari egosentris remaja yang meliputi perasaan unik seorang anak remaja. Perasaan unik pribadi remaja menjadikan mereka merasa bahwa tidak seorangpun dapat memahami bagaimana isi hati mereka yang sesungguhnya. Sebagai bagian dari upaya mempertahankan perasaan unik pribadi, remaja sering mengarang cerita tentang dirinya sendiri yang dipenuhi fantasi, yang menceburkan diri mereka ke dalam suatu dunia yang jauh terpencil dari realitas. Dongeng-dongeng pribadi ini sering ditemui dalam buku harian remaja.

Dari penjelasan di atas sifat egosentris dongeng pribadi yang dimaksud adalah suatu sifat dimana remaja merasa tidak ada seorangpun yang mengerti perasaannya. Dengan demikian pada diri remaja untuk mengemukakan bahwa pemikiran yang belum matang ini memanifestasikan dirinya sendiri kedalam enam karakteristik diantaranya idealisme dan kekritisan, argumentativitas, ragu-ragu, dan menunjukan hipocrisy, kesadaran diri, kekhususan dan ketangguhan. ${ }^{15}$

a. Idealisme dan Kekritisan. Remaja biasanya memimpikan dunia yang ideal. Mereka terlalu percaya bahwa mereka mengetahui bagaimana cara mengatur dunianya dengan lebih baik daripada orang dewasa, dan mereka sering membuat kesalahan dengan orangtuanya, mereka acuh terhadap nasehat yang diberikan oleh orang tua sehingga disini sifat egosentris sangat tampak sekali.

b. Argumentativitas. Remaja selalu mencari kesempatan untuk mencoba dan mempertunjukkan kemampuan penalaran mereka. Mereka memiliki banyak alasan (berargumen) untuk menyanggah sehingga apa yang mereka sanggah itu bagi diri remaja merupakan hal yang benar.

c. Indecisiveness. Remaja tidak dapat mengambil keputusan yang pasti diantara berbagai alternatif yang ada karena belum adanya pengalaman sehingga mereka tidak mempunyai strategi yang efektif untuk memilih.

${ }^{15}$ Diane E. Papalia, Human Development,( Jakarta : Kencana Pernanda Media Group), hal. 561 
d. Ragu-ragu. Pada diri remaja mengalami suatu keragu-raguan dalam mengambil suatu keputusan sehingga inipun merupakan suatu proses pencapaian identitas diri.

e. Kesadaran diri. Remaja sudah dapat berpikir tentang apa yang dipikirkan oleh diri mereka sendiri maupun orang lain. Tetapi, remaja seringkali berasumsi bahwa orang lain tengah berpikir hal yang sama dengan mereka, yaitu memikirkan tentang diri mereka. Seorang remaja perempuan akan merasa malu ketika dia memakai pakaian yang salah dalam suatu pesta, dia akan berpikir bahwa orang lain akan melihat ke arahnya.

f. Kekhususan dan ketangguhan. Remaja menganggap dirinya unik dan menganggap bahwa sesuatu yang buruk yang menimpa orang lain tidak akan terjadi padanya.

Masih merujuk pada teori Erikson beliau mengemukakan bahwa adanya suatu yang dimiliki oleh ego yakni kepercayaan dan penghargaan, otonomi dan kemauan, kerajinan dan kompetensi, identitas dan kesetiaaan, keakraban dan cinta, generativitas dan pemeliharaan, serta integritas. ${ }^{16}$ Dari hal yang telah dikemukan tersebut menurut penulis Ego tenyata dapat menemukan pemecahan kreatif atas masalah baru yang telah dihadapi atas setiap suatu tindakan yang dilakukan karena disini Ego bukan suatu budak lagi namum dapat mengatur Id dan Superego dan dibentuk oleh konteks kultural dan historik. Hal ini sesuai yang dikemukan oleh Erikson beliau mengemukakan :

.. Ego menang ketika tindakan-tindakan defensifnya.... memungkinkannya untuk membatasi perkembangan kecemasan dan mentranformasikan insting-insting sehingga, bahkan didalam keadaan-keadaan sulit, tindakan pemuasan tertentu dapat dipastikan, sehingga membangun hubungan-hubungan yang paling serasi yang mungkin terjadi antara id, sufer-ego dan kekuatan kekuatan dunia luar. ${ }^{17}$

Adapun Ego yang sempurna, sesuai yang dikemukakan oleh Erikson, yang penulis temui adalah faktualitas, universal dan akuntalitas ${ }^{18}$. Dari yang dikemukan oleh Erikson penulis menganalisa ketiga ego tersebut sebagai berikut:

1. Faktualitas. Menurut penulis Faktualitas yang dimaksud disini adalah suatu kumpulan fakta, data, dan metode yang dapat diverifikasi dengan metode kerja yang sedang berlaku. Artinya suatu kebutuhan pemuasan yang diperoleh dari kumpulan data dan fakta yang diperoleh dari hasil suatu interaksi dengan lingkungan sekitar.

\footnotetext{
${ }^{16}$ Syamsu Syusuf, Teori Kepribadian, (Bandung: Remaja Rosdakarya, 2008). hal. 115

${ }^{17}$ Erik H. Erikson, Childhood and Society, (Yokyakarta: Pustaka Pelajar, 2010) . hal. 223

${ }^{18} \mathrm{Http}$ :/ / www.you.com/articles/adolescent-erk. Diunduh pada tanggal 12 Februari 2019, pkl. 16.00 WIB
} 
2. Universalitas. Menurut penulis Univesalitas adalah suatu hal yang berkaitan dengan kesadaran akan kenyataaan yang menghubungkan hal yang praktis dan kongrit dengan pandangan semesta.

3. Akuntalias. Menurut penulis Aktualitas adalah cara baru dalam berhubungan satu dengan yang lain memperkuat suatu hubungan. Selain itu dalam mencapai perkembangan identitas diri, dalam dorongan pribadi pada prinsipnya pada diri remaja terjadi suatu perasaan yang dapat mengubah pribadinya sehingga perasaan itu nantinya akan mempengaruhi pada diri indentitas selanjutnya. Adapun yang penulis temui perasaan yang terjadi pada diri remaja yaitu;

a. Pembelaan diri yang tidak disadarinya. Pembelaan diri yang tidak disadari yang dimaksud disini adalah dimana individu bermaksud mengemukakan alasan alasan yang tampaknya logis bagi akal, akan tetapi sebenarnya bukanlah merupakan sebab hakiki. Sering kali kita berusaha membenarkan beberapa tingkah laku yang dilakukan para remaja, yang pada dasarnya mengekspresikan keinginankeinginan yang terpendam. Oleh sebab itu tatkala perilaku seorang keluar dari batas yang logis dan diterima masyarakat, remaja mengambil trik ini, sehingga dia bisa menjelaskan kepada dirinya dan kepada semua orang bahwa perilakunya bisa diterima, tidak ada yang salah. Artinya dia menjustifikasikan perilakunya agar tampak logis dalam pandangannya dan pandangan orang lain sehingga penerimaan yang dilakukan oleh masyarakat nantinya akan mempengaruhi identitas diri pada remaja.

b. Menebak orang lain dengan sifat-sifat tercelanya. Pada diri remaja penulis sering melihat adanya karakteristik egosentris yang ditampilkan remaja bahwa itu semua adalah benar sehingga dia tidak peduli akan apa yang dikatakan individu lain. Menebak orang lain dengan sifat-sifat tercela yang dimaksud disini adalah suatu trik defensif bawah sadar dimana seorang individu sering menebak orang lain dengan sifat-sifat tercelanya. Dimana remaja mengecap orang lain dengan sifat yang ada dalam dirinya yang tidak disukainya. Maksudnya disini adalah kita sering melihat pada diri remaja memiliki karakteristik sifat aklak yang tercela dimana sifat ego pada diri remaja menurut Erikson tahap ini merupakan puncak perkembangan yang krisis. Senada dengan pendapat Sarwono yang menyatakan:

Bahwa perilaku yang dilakukan remaja tidak selalu merupakan gejala yang mengacu pada tekanan ekonomi, sosial serta kelompok sub-budaya, tetapi sering merupakan fenomena yang mengacu pada situasi pribadi remaja itu sendiri. Ini seiring dengan berkembangnya psikologisnya, remaja cenderung berperilaku sesuai dengan harapan dan keinginan serta 
penilaiannya sendiri. Keadaan ini membuat remaja sulit menerimanya apabila tidak sesuai dengan harapan sehingga remaja mencari pelarian dari keadaan yang tidak menyenangkan tersebut. 19

Dimana kita sering melihat remaja tidak jarang mau mengakui apa yang ia perbuat itu sebenarnya salah. Semua itu tidak lain merupakan suatu proses yang ada pada diri remaja dalam mencapai suatu identitas diri.

c. Ingin menjadi orang lain. Sesuai dengan yang dikemukan oleh Erikson pada diri remaja terdapat sifat egosentris penonton khayalan yang mengemukana bahwa banyak diri remaja pada tahap ini ingin diri orang lain yang ditirunya karena di sini tujuannya tidak lain ingin mencari perhatian. Maksud ingin menjadi orang lain disini adalah diri remaja dalam mencapai perkembangan identitas diri kadang mereka ingin langsung menceburkan keperibadiannya secara total dalam kepribadian orang lain. Misalnya kita sering melihat banyak remaja yang ketika gaya berpakai orang jaman sekarang merekapun mengikutinya atau melihat individu lain merokok hebat dia ingin juga untuk mencoba merokok. Ini semua merupakan proses pencapaian identitas diri.

d. Pertahanan diri. Pertahanan diri yang dimaksud disini adalah merupakan suatu sifat yang tidak sedikit sering terjadi pada diri remaja untuk menghindari kesalahan yang dia perbuat. Karena sifat pertahanan diri ini merupakan suatu hal yang terbaik menurut remaja dalam memecahkan permasalahan yang dihadapai dan mengurangi ketegangan, tanpa mengakibatakan orang lain mengetahui motivasimotivasi dalam dirinya yang tidak dapat diterima masyarakat. Dengan cara ini, seorang individu berusaha mencapai tujuan-tujuan yang baik yang berbeda tujuantujuan aslinya yang tidak bisa diterima masyarakat.

Berkaitan dengan hal diatas yang telah dikemukakan oleh Erikson menurut penulis pencapaian perkembangan egosentris remaja dalam mencapai identitas diri itu menghasilakan suatu implikasi tersendiri. Dimana pada bab sebelumnya telah dijelaskan suatu prilaku individu remaja itu cendrung mengarah kepada kepentingan terhadap diri-sendiri dan keasikan terhadap diri sendiri dan cara untuk memandang pada hal-hal yang diterimanya baik hal hal yang positif maupun hal-hal yang negative yang didapatkannya dari lingkunganya. Apabilah yang diterimanya individu itu cendrung positif maka perkembangan egonya akan baik, namun apabila yang diterimanya bersifat negative, maka akan menganggu perkembangan

${ }^{19} \mathrm{http}: / /$ www.you.com/articles/adolescent-agresi. Diunduh pada tanggal 12 Februari 2019, pkl. 16.00 WIB 
ego individu untuk menjadi yang diinginkan. Implikasi tersebutlah yang kelak membentuk identitas pada diri remaja.

\section{Bentuk Implikasi pada Identitas Diri Remaja}

1. Keinginan remaja yang membentuk suatu organisasi

Pada usia remaja disini ingin dan berharap dapat diterima oleh masyarakat. Sebagai suatu bukti bahwa dirinya sudah mampu berbuat dan bertindak layaknya orang dewasa. Sebagai akibat dari keinginan tersebut maka remaja membentuk suatu organisasi atau bergabung dengan suatu kelompok/organisasi. Mereka akan berusaha bersatu dengan kelompok yang selama ini ditentang pada masa tahap negatif. Artinya disini pada diri remaja mereka akan selalu menentang kewibawaan orang dewasa sebagai akibat masa remajanya agar di akui sesuai dengan perkembangan mereka. Oleh karena itu penulis sering melihat pada diri remaja sering mengedepankan egosentrisnya dalam melakukan suatu tindakan. Selain itu biasa dalam suatu kelompok/ organisasai remaja terikat dalam suatu kelompok teman sebaya. dimana dia berupaya keras agar dapat terlibat dalam suatu kelompok tersebut dan berjuang untuk menkokohkan kedudukannya serta mengadopsi nilai-nilai perilaku yang dipegang oleh kelompoknuya. Hal ini sesuai yang dikemukakan oleh Musthofa Fahmi yang menafsirkan bahwa kesetiaan kelompok terhadap suatu kelompok itu merupakan upya remaja untuk meringankan kuatnya perasaan dosa yang muncul karena dia membangkang terhadap kedua orang tuanya, keluarganya dan guru-gurunya ia berkata ${ }^{20}$ :

"Yang mendorong remaja untuk menyelaraskan diri dengan kelompoknya pada permulaan fase remaja, adalah usahanya untuk menghindari segala hal yang menyebabkan muncul pertikaian antara anggota-anggota kelompok ini. Ketika melakukan itu, dia melihat bahwa setiap pertikaian antara dirinya dnegan mereka dianggap tidak seberapa bila dibandingkan dengan pertikaian terbesar yang terjadi antara dia dan otoritas sekolah dan orang tua. Karena itu penghormatanya kepada visi kelompok, ketulusanya kepada mereka dan kedudukanya kepada ide-ide pemikiran mereka mengandung semacam peringanan perasaan berdosa yang timbul dari ketidaktaatanya kepada orang tua dan guru-guru."

Kembali kepada pengalaman-pengalaman yang diperoleh remaja yang tadi telah dijelaskan diatasa bahwa kalangan remaja yang mendapatkan pengalaman, pendidikan, dan asuhan yang baik dari orang tua serta berada dalam lingkungan yang baik pula. Maka itu akan berpengaruh juga pada diri remaja. Sebaliknya bila remaja bertolak belakang dengan latar kehidupannya maka akan berdampak pada diri remaja artinya remja akan terjerumus pada identitas diri yang negatif.

20 Sayyid Muhamad, Pendidkan Remaja Antara Islam dan Ilmu Jiwa, (Jakarta: Katalog Dalam Terbitan, 2007).hal. 172-123 


\section{Keinginan Remaja dalam Mencari Tantangan Hidup}

Mencari tantangan hidup yang dimaksud disini maksudnya adalah penulis sering melihat banyak remaja yang tidak memperdulikan keselamatan jiwa dan raganya. Kita sering melihat secara realitas banyak remaja disekitar kita yang melakukan keonaran, kebiasaan yang kadang kala dapat membuat kerugian baik dirinya maupun orang lain misal ngebut-ngebutan di pinggir jalan yang dianggap remaja sebagai suatu tantangan yang sangat menyenangkan dan tidak memikirkan resiko apa nanti yang bakal diterimanya. Sikap itu sesuai yang dicetuskan oleh Erikson bahwa di dalam diri remaja terdapat sifat egosentris yang mencermikan pola pikir idealisme dan kekritisan. Dimana remaja biasanya memimpikan dunia yang ideal. Mereka terlalu percaya bahwa mereka mengetahui bagaimana cara mengatur dunianya dengan lebih baik daripada orang dewasa, dan mereka sering membuat kesalahan dengan orangtuanya, mereka acuh terhadap nasehat yang diberikan oleh orang tua sehingga disini sifat egosentris sangat tampak sekali yaitu acuh terhadap nasehat orang tua. Semua itu tidak lain dalam pengamatan penulis merupakan proses pencarian identitas diri. Perlu kita ketahui pada masa ini bukan berarti remaja tidak mengerti akan resiko yang dihadapinya. Tetapi ini merupakan suatu sikap egosentrisnya yang merupakan tahapan yang harus mereka wujudkan dalam mencapai perkembangan identitas diri.

\section{Remaja dalam Mencari Kepuasan Hati dan Perasaan}

Dalam mencari kepuasan hati dan perasaan kadang kita melihat pada diri remaja selalu menentang kehendak orang tua. Misalnya disini kebijakan oran tua yang terkadang tidak didengarkan. Dalam hal ini bukan berarti remaja hanya melakukan hal yang negatif, namun juga bisa bersifat positif. Semua tergantung dengan perasaan (emosi), pendidikan, pengalaman dan kasih sayang yang diterimanya. Apabila mereka sedang banyak masalah maka remaja akan cendrung melakukan hal yang negatif, yang ada dalam benaknya hanya bagaimana agar bisa bergembira dan menikmatinya setiap saat. Dan sebaliknya bila kondisi psikologisnya sedang tidak bermasalah maka dia akan mencari kesenangan yang bersifat positif.

Selain itu dari paparan yang telah dijelaskan mengenai berbagai tindakan yang mengedepankan sifat egosentris ternyata ini semua merupakan suatu kegiatan dalam rangka memenuhi kebutuhan (needs) dirinya dimana pada bab sebelumnya telah disinggung pada diri remaja menurut Murray ada kebutuhan psychogenic yaitu kebutuhan sosial. Dimana kebutuhan sosial yang dimaksud disini adalah kebutuhan yang merupakan suatu kebutuhan pada diri remaja yang nantinya sangat berpengaruh terhadap perkembangan identitas diri selanjutnya. Kebutuhan sosial yang dimaksud tersebut menurut penulis adalah sebagai berikut ; 
a. Pada diri remaja disini mereka menginginkan suatu kebutuhan merasa perlu mendapat hukuman apabila berbuat kesalahan artinya pada saat remaja melakukan suatu tindakan maka pada saat itu pula ada suatu kebutuhan yang perlu diingatkan pada dirinya sehingga apa yang dilakukan itu adalah salah sehingga dari kesalahan itu dirinya mengakuinya.

b. Pada diri remaja menginginkan kebutuhan untuk melakukan tindakan kekerasan dengan tindakan kekerasan inilah kita sering melihat remaja melakukan suatu tindakan kriminal seperti tawuran atau perkelahian

c. Pada diri remaja menginginkan kebutuhan untuk bertindak secara mandiri, menyatakan kebebasan diri untuk berbuat atau mengatakan apapun, bebas dalam mengambil keputusan. Sehingga dalam hal ini kita sering temui pada diri remaja sifat menentang terhadap orang tua yang mana telah dijelaskan diatas sebelumnya.

d. Pada diri remaja menginginkan kebutuhan untuk memamerkan diri yang mana sebelumnya kita kenal istilah egosentris sifat penonton khayalan dimana pada diri remaja sering sekali memperlihatkan dirinya agar menjadi suatu pusat perhatian orang lain. Sehingga sering kita lihat remaja dalam hal ini remaja megngunakan bahasabahasa gaul yang hanya dipahami oleh teman sekelompoknya sendiri.

Dengan demikian dari penjelaskan diatas dapat disimpulkan semua sikap yang dilakukan pada diri remaja tersebut merupakan suatu sikap yang mana ini semua merupakan suatu proses pencapaian perkembangan identitas diri yang terjadi pada diri remaja dengan beberapa kebutuhan tersebut dapat terpenuhi maka akan terbentuklah identitas diri yang positif.

\section{Implikasi Spiritual Remaja dalam Mencapai Perkembangan Identitas Diri}

Perkembangan kehidupan spiritual pada remaja tidak dapat dilepaskan dari pembinaaan kepribadian secara keseluruan. Karena kehidupan spiritual remaja adalah bagaian dari kehidupan sendiri, sikap atau tindakan seorang dalam hidupnya tidak lain dari panutan pribadinya yang bertumbuh dan berkembang sejak ia lahir, semenjak berada dalam kandungan (Zakia Drajad) ${ }^{21}$. Semua pengalaman dilalui sejak dalam kandungan, mempunyai pengaruh terhadap pertumbuhan pribadi bahkan diantara ahli jiwa ada yang berpendapat bahwa pribadi itu tidak lain adalah kumpulan pengalaman pada usia-usia terdahulu.

Sejalan dengan pertumbuhan jasmani dan perkembangan psikologis serta mulai matangnya fungsi intelektual remaja, maka remaja dalam menghayati agamanya juga dipengaruhi oleh perkembangan dan pertumbuhan., yang mana pada bab sebelumnya telah dijelaskan ada beberapa sikap dan keyakinan spiritual remaja dalam mencapai perkembangan

${ }^{21}$ Akmal Hawi, Ilmu Jiwa Agama, (Palembang: Katalog Dalam Terbitan (KDT), 2005).hal.200. 
identitas diri.nUntuk melihat bagaimana implikasi perkembangan spiritual remaja dalam mencapai perkembangan identitas diri, mari kita bahas implikasi identitas diri sesuai dengan perkembangan keagamaan pada diri remaja sesuai yang dikemukakan oleh Sururin.

Adanya suatu sikap pribadi remaja yang percaya dan ikut-ikutan disini tergambarkan bahwa remaja yang sejak kecil yang terdidik dalam lingkungan yang beragama, teman-teman, masyarakat sekitarpun rajin beribadah, maka mereka ikut percaya dan melaksanakan ibadah serta mengikuti ajaran agama sekedar mengikuti suasana lingkungan dimana ia hidup. Kebiasaan masa kecil inilah yang membuat masa remaja selalu bersikap apatis dan tidak mau aktif dalam kegiatan-kegiatan agama.

Identitas diri ini muncul apabila orang tuanya memberikan pendidikan agama dengan cara menyenangkan. Dengan cara seperti itu nantinya identitas remaja yang akan datang akan berdampak positif, jauh dari pengalaman-pengalaman pahit di masa kecil dan setelah dia menjadi remaja, tidak mengalami pula peristiwa-peristiwa yang menggoncangkan jiwanya, sehingga cara kekanak-kanakan dalam beragama itu terus berjalan tanpa ditinjau kembali. Namun apabila dalam masa remaja tersebut mereka menemukan peristiwa-peristiwa yang mendorong untuk meneliti kembali pengalaman-pengalaman masa kecil, maka kesadaran identitas dirinya akan tumbuh. Sehingga bisa jadi dia bersemangat sekali, ragu-ragu, atau bahkan anti agama. Artinya identitas diri disini besar juga dipengaruhi didikan lingkungan beragama yang beragama, karena disini mereka akan percaya dan meyakini serta melaksanakan ajaran agama sesuai lingkungan yang remaja lihat apabila lingungan remaja kental dengan nilai-nilai spiritual maka identitas remajapun akan mengalami spiritual, sebaliknya apabila lingkungan didikannya tidak spiritual maka terjadi pula identitas diri yang tidak spiritual. Biasanya proses pencapaian identitas ini terjadi pada masa remaja awal usia berkisar 13-16 tahun.

Setelah mereka melewati masa usia tersebut pada diri remaja kembali, pada diri remaja akan terjadi suatu perkembangan jiwa keagamaan yang lebih kritis dan lebih sadar. Seperti suatu sikap percaya dengan suatu kesadaran artinya di sini kita akan melihat setelah yang tadi dijelaskan bahwa masa remaja setelah mengalami goncangan pada usia remaja awal maka disini remaja sudah akan mulai berfikir lebih matang dan pengetahuannyapun semakain bertambah. Dengan bertambahnya pola pikir dan pengetahuan remaja di sini maka semakin juga pada diri remja akan mengalami suatu masa sensitif artinya remaja tenggelam lagi dalam memikirkan dirinya sendiri.

Remaja disini mengambil suatu tempat dan menonjol dalam masyarakat, ketertarikan terhadap pengetahuan, nilai-nilai keagamaan dan soal-soal sosial remaja tumbuh bertamba besar. Kadang kita sering melihat pertumbuhan identitas diri remaja kadang mengalami 
pertumbuhan secara abnormal atau kadang kala menyimpang seperti bergabung dalam ganggang nakal,. Akan tetapi sebaliknya masa ini juga timbul suatu kesadaran agama yang berlebihan dan juga pada masa ini terjadi suatu identitas diri pada remaja yaitu suatu kepatuhan dan ketundukannya kepada ajaran tanpa komentar atau tak lagi menggembirakannya. Kita sering melihat mengapa remaja ketika dilarang melakukan sesuatu karena norma agama disini terjadi suatu identitas diri dimana remaja tidak akan merasakan puas apabila alasan yang disampaikan hanya melalui suatu hadis atau ayat al-quran. Disini remaja ingin menjadikan agama sebagai suatu lapangan baru untuk mencapai identitas yang memang untuk diri pribadinya sehingga pada remaja akan tumbuh suatu sikap semangat yang tinggi yaitu identitas diri semngat yang positif dan identitas diri semangat yang negatif. Adapun kedua semangat identitas diri tersebut meliputi:

1. Identitas diri semangat agama remaja yang positif.

Menurut penulis Identitas diri yang dimaksud disini adalah suatu identitas diri dimana pada jiwa keagamaan pada diri remaja disini mengalami suatu sikap pandang yang kritis terhadap agama. Disini remaja tidak mau lagi menerima hal-hal yang tidak masuk akal.karena pada tahap ini remaja sudah mulai berfikir secara rasional. Identitas diri agama pada remaja ini terlihat dari suatu sikap dan tindakan dimana individu ini mempunyai suatu semangat agama yang positif. Ini akan terlihat dari dua kepribadian yang dikemukan oleh Zakia Drajad yaitu ekstrovert dan introvert. Identitas diri yang ekstrovert yaitu suatu identas diri terbuka yang terjadi pada diri remaja dimana di sini remaja yang memiliki kepribadian terbuka akan menampilkan identitas diri yang mudah mengungkapkan perasaannya kepada orang lain. Artinya individu ini mempunyai kepribadian yang terbuka dengan menunjukkan aktivitas agamanya ke dunia luar berupa kegiatan-kegiatan sosial, seperti aktif dalam Remaja Masjid, dan mereka berkecenderungan untuk mengembangkan agamanya secara terus menerus sesuai pertumbuhan yang dialaminya.Sedangkan Identitas diri yang Introvert yaitu suatu identitas diri yang mana di sini individu mengalami kecenderungan menyendiri dan menyimpan perasaannya untuk dirinya sendiri. Artinya disini remaja yang mengalami sikap seperti ini biasanya jarang menghabiskan aktivitasnya di luar

2. Identitas diri semangat agama remaja yang negatif

Menurut penulis Identitas diri semangat remaja yang negatif yaitu suatu identitas diri pribadi remaja yang cendrung dalam memperdalam suatu agama remaja mengambil unsurunsur luar dan mencampurkan ke dalam agama dan keyakinannya. Biasanya remaja yang mengalami identitas seperti ini meyakini adanya pengaruh setan, jin, benda keramat, kuburan dan lain-lain. Semangat identitas diri remaja ini seringkali bersifat khurafi, biasanya sifat ini 
terjadi kepada remaja yang ekstrovet yaitu remaja yang memiliki kepribadian terbuka. Misalnya disini remaja biasanya selalu mengajak teman-temanya untuk mendatangi dukun setiap kali untuk menghadapi masalah dan remaja percaya bahwa si dukun adalah tempat yang pas dalam memecahkan masalah. Berbeda dengan remaja yang memiliki identitas diri yang tertutup. Remaja di sini percaya akan apa yang ia percayai dan remaja di sini hanya tenggelam sendiri sehinggga biasanya identitas diri remaja seperti ini hanya dipendam dan berusaha untuk mengatasi dirinya sendiri.

Selain itu dalam uraian sebelumnya menurut penulis sikap dan perkembangan pada diri remaja ternyata disini pada diri remaja mengalami suatu kebimbangan beragama yang mana kalau kita kaitkan dengan teori Erikson diatas ini sama dengan pada tahapan yaitu pada diri remaja itu dikenal Identitas versus Kebingungan Identitas (Identitas versus Kebingungan Peran) artinya di sini remaja akan mengalami kontradisksi atau kebingungan peran sehingga akan menyebakan suatu kebimbangan jiwa dalam beragama.

Kebimbangan beragama pada remaja dipengaruhi oleh dua faktor yaitu:

1. Kebimbangan yang disebabkan karena goncangan jiwa dan terjadinya suatu proses perubahan pada identitas diri pribadinya. Maksudnya adalah pada diri remaja kebimbangan ini terjadi pada diri remaja telah mengalami kematangan dalam berfikir sehingga biasanya sering kita lihat adanya sikap remaja yang kadang kala menerima dan menolak apa yang diterangkan pada diri remaja. Sehingga tidak heran sifat egosentrispun muncul pada tahap ini. Inipun merupakan suatu prose pertumbuhan identitas diri pada remaja dalam mencapai identitas diri yang baik.

2. Kebimbangan yang disebabkan adanya kontradiksi atas kenyataan yang ia lihat dengan pengetahuan yang dimiliki. Seperti pertentangan nilai-nilai moral yang ia ketahui dengan realitas yang ada di masyarakat yang ia lihat. Maksudnya di sini adalah pada diri remaja disini kita akan melihat adanya suatu kontradiksi yang terjadi pada remaja yang diakibatkan pada masa lalunya tidak sesuai yang diterima saat sekarang sehingga membuat identitas diri remaja mengalami suatu kebimbangan.

Dengan demikian sesuai yang dikemukan oleh Zakia Drajad bahwa kebimbangan dan kegoncangan keyakinan yang terjadi sesudah perkembangan kecerdasan tak dapat dipandang sebagai suatu kejadian yang berdiri sendiri, tetapi hubunganya dengan segala pengalaman dan proses pendidikan yang dilaluinya sejak kecil22. Hal ini karena pengalaman-pengalaman yang remaja terima akan membentuk suatu identitas diri yang baik.

22 Bambang Samsul Arifin, Psikologi Agama, (Bandung : Pustaka Setia, 2008), hal. 75 
Dalam perkembangan spiritual, remaja mencapai identitas dirinya terdapat suatu identitas diri yang dikenal dengan Ateis artinya pada diri remaja terbentuk suatu identitas diri yang ditimbulkan sebagai akibat suatu proses pola asuh kedua orang tua. Pola asuh yang salah terhadap diri remaja akan membuat suatu identitas diri remaja yang akan tertekan artinya apabila orang tua mendidik anak dengan sistem yang tidak sesuai atau harapan yang diingikan remaja maka kelak akan terjadi identitas diri remaja yang negatif, misalnya ada remaja yang sering memberontak baik terhadap orang tuanya maupun terhadap agama, ini semua diakibatkan adanya pola asuh orang tua yang salah dalam mendidik anak. Selain itu ada faktor yang mendorong remaja kadang tidak percaya terhadap Tuhan yaitu dorongan seksual yang kadang membuat mereka ingkar akan agama (adanya Tuhan). Misalnya remaja yang seksualnya tidak terpenuhi ia akan mengalami identitas diri yang mudah kecewa artinya ada suatu dampak pada identitas diri pada diri remaja yang menyebakan dirinya kecewa, dan kekecewaannya itupun berlanjut ke perasaan pesimis dan putus asa.

Selain itu dalam mencapai perkembangan spiritual dalam identitas diri remaja ada suatu istilah dalam psikoanalisis yang dikemukan oleh Frued yaitu adanya Superego pada diri remaja. Dimana menurut teori Frued, Superego yang terjadi pada diri remaja merupakan bagian dari jiwa yang berfungsi mengendalikan suatu tingkah laku ego yang telah terjadi sehingga adanya suatu penerimaan dari masyarakat, dimana Superego ini muncul melalui jalan internalisasi (penyerapan) yang diperoleh dari luar khususnya adalah orang tua itu sendiri. Artinya terbentuknya suatu identitas diri yang spiritual pada diri remaja menurut psikoanalisa itu dipengaruhi besar oleh orang tua. Selain itu menurut aliran psikoanalisis remaja yang tidak mempunyai hubungan yang harmonis dengan orang tuanya diamasa kecil kemungkinan besar tidak akan dapat mengembangkan Superego yang cukup kuat. Artinya spiritual pada diri remaja akan mengalami kekaburan identitas diri yang tidak mantap sehingga wajar kita sering melihat banyaknya remaja yang melanggar aturan-aturan masyarakat.

Penulis melihat adanya peranan yang sangat penting dalam mewujudkan pencapaian spiritual remaja terhadap identitas dirinya yaitu adalah peran kontrol masyarakat itu sendiri. Adapun kontrol yang dimaksud adalah sebagai berikut 1) perilaku yang lazim yang biasanya penulis lihat seperti makan dengan tangan kanan; 2) tingkah laku yang sebaiknya dilakukan misalnya mengucapkan terima kasih atas jasa seseorang atau memberi salam pada waktu berjumpa; 3) tingkah laku yang harus dihindari atau dilakukan misalnya tidak boleh mencuri dan harus membayar hutang.

Ketiga contoh kontrol diatas merupakan suatu hal yang dapat membentuk identitas spiritual remaja yang mana sesuai yang dikemukan oleh pada bab sebelumnya salah satu karakteristik spitual itu adanya suatu kesadaran diri yang tinggi, maksudnya apapun yang ia 
lakukan itu dengan kesadaran. Seperti yang ditegaskan oleh Zonar dan Ian Marsal, bahwa manusia ini berbeda dengan mesin. Manusia adalah mahluk tuhan yang memilki kesadaran (human being are conscious). Selanjutnya teori Kollberg menyatakan perkembangan spiritual pada diri remaja dikenal dengan perkembangan moral, artinya orang yang bertindak sesuai dengan moral adalah orang yang mendasarkan tindakan atas penilaian baik buruknya sesuatu. Karena sifatnya yang merupakan penalaran, maka makin tinggi tingkat penalaran seorang makin tinggi pula penalarannya.

Penalaran yang dimaksud disini adalah penalaran gaya berfikir remaja tentang nilai-nilai spiritual, dimana perkembangan moral pada diri remaja juga merupakan hal yang terpenting dalam perwujudan pencapaian identitas diri pada remaja, karena disini sesuai deng tingkat perkembangan kognisi yang mulai mencapai tahapan berfikir operasional formal yaitu mampu berfikir abstrak dan mampu memecahkan permasalahan yang bersifat sementara. Maka pemikiran remaja terhadap suatu permasalahan tidak lagi hanya terikat pada waktu, tempat dan situasi tetapi juga pada sumber moral yang menjadi dasar hidup mereka dimana tadi telah disinggung munculnya suatu kesadaran diri akan kewajiban mempertahankan kekuasaan dan pranata yang ada karena remaja menganggap itu merupakan suatu hal yang bernilai, walaupun pada tahap ini remaja belum mampu mempertangung jawabkan secara pribadi.

Merujuk kepada teori Erikson, Piagert dan Kohlberg yang mengemukakan bahwa pada diri remaja dalam mencapai perkembangan spiritual untuk mencapai identitas diri, terbagi menjadi dua tahapan yaitu tahap remaja awal dan tahap remaja akhir. Tahap remaja awal mulai mengembangkan pemikiran operasional dan mulai mengintergrasikan nilai-nilai agama yang telah mereka pelajari kedalam suatu sistem kepercayaan yang lebih rasional adapun pemikiran yang operasional remaja dalam mencapai identitas diri menurut penulis adalah Mengenai keberadaan sifat kemurahan dan keadilan Tuhan mulai dipertanyakan secara kritis, Penghayatan kehidupan keagamaan sehari-hari dilakukan mungkin didasarkan atas pertimbangan adanya semacam tuntutan yang memaksa dari luar dirinya, dan Masih mencari dan mencoba menemukan pegangan hidupnya.

Dan begitu juga pada tahap remaja akhir yaitu remaja sudah mampu mengambil tangung jawab penuh terhadap kepercayaan agama mereka. Mereka mulai menyatakan bahwa mereka dapat memilih jalan kehidupan mereka sendiri dan mereka harus berusaha keras untuk mengikuti satu jalan kehidupan tertentu. Adapun menurut penulis pada diri remaja akhir dalam mencapai identitas diri spirtitual adalah Keberadaan dan sifat kemurahan serta keadilan Tuhan mulai dipahamkan dan dihayati menurut sistem kepercayaan atau agama yang dianut, Penghayatan dan pelaksanaan kehidupan keagamaan sehari-hari mulai dilakukan atas dasar kesadaran dan pertimbangan hati nuraninya sendiri yang tulus ikhlas. Jadi dengan demikian 
kedua tahapan yang telah penulis jelaskan di atas merupakan suatu konsep pada diri remaja dalam menumbuhkan nilai-nilai spiritual remaja sehingga terbentuklah identitas diri remaja sesuai dengan pengalaman yang diterimanya dalam proses tersebut.

\section{KESIMPULAN}

Implikasi egosentris dalam mencapai perkembangan identitas diri, ada suatu perkembangan yang sangat berpengaruh terhadap identitas diri pada diri remaja yaitu istilah yang dikenal egosentris. Dalam kajian ini penulis melihat begitu besar implikasi egosentris dalam suatu proses perkembangan identitas diri. Keterlibatan egosentris inilah yang ditampilkan oleh para remaja melalui suatu sikap atau tindakan untuk mencapai perkembangan identitas diri. Karena apabilah sikap atau tindakan ini salah penempatan maka akan berdampak negative bagai remaja. Artinya dalam proses pertumbuhan perkembangan pada masa remaja. Sifat egosentris ini memiliki peran penting dalam perkembangan idetitas diri.

Dalam proses pencarian identitas diri, remaja dalam bertindak atau bersikap selalu mengedepankan sifat egosentrisnya. Artinya dalam melakukan suatu tindakan remaja selalu memperlihatkan sifat egosentrisnya yaitu memandangg hal-hal yang diterimanya, baik yang positif maupun hal-hal yang bersifat negative yang didapatnya dari lingkungan. Apabilah yang diterima individu itu cendrung positif maka perkembangan egonya akan baik, namum apabilah yang diterimanya bersifat negative maka akan menganggu perkembangan ego individu untuk menjadi yang diinginkanya. Adapun sifat yang mengedepankan egosentris pada diri remaja ialah suka berdebat, memberontak, mengkritik, melawan otoritas, pertahanan diri, ragu-ragu, idealisme dan lain-lain. Sehingga dari hal tersebutlah harapan kita remaja dapat melibatkan suatu tindakan tersebut pada hal yang postif serta mengikut sertakan remaja dalam berperan aktif dalam suatu kegiatan-kegiatan yang positif. Misalnya dalam kegiatan organisasi.

Implikasi spiritual dalam mencapai perkembangan identitas diri, perkembangan spiritual remaja tidak dapat dilepaskan oleh pembinaan kepribadian secara keseluruhan. Karena perkembangan spiritual remaja adalah bagian dari kehidupan sendiri. Artinya sikap dan keyakinan spiritual seorang dalam hidupnya tidak lain dari panutan pribadinya yang bertumbuh dan kembang sejak lahir terutama semenjak dalam kandungan. Berkaitan dengan implikasi spiritual remaja dalam mencapai perkembangan identitas diri. Pada diri remaja terdapat suatu sikap dan keyakinan yang diperoleh dari pengalama-pengalaman terdahulu. Artinya kosep keyakina spiritual itu terbentuk atas pengalaman-pengalaman yang telah terjadi yang akhirnya kan berpengaruh terhadap identitas diri selanjutnya. 
Adapun identitas spiritual yang muncul dalam pertumbuhannya ialah adanya tindakan ikut-ikutan, percaya dengan kesadaran, kebimbangann serta ketidak percayaan terhadap tuhan. Jadi sikap dan keyakinan itu semua akan berimplikasi terhadap identitas selanjutnya. Dengan demikian kedua implikasi egosentris dan spiritual remaja dalam mecapai perkembangan identitas diri merupakan suatu proses yang perlu sekali kita respon dan kita sikapi sehingga untuk merespon dan menyikapi hal-hal yang negatif yang terjadi pada diri remaja sebaiknya harapan kita peran aktif orang tua dan masyarakatlah yang memberikan pengertian dan arahan yang bijaksana. Sehingga harapan kita generasi muda yang akan datang berdaya guna dalam menyonsong kehidupana harapan bangsa dan negara.

\section{DAFTAR RUJUKAN}

Al Mighwar, Psikologi Remaja, Bandung: Pustaka Setia, 2006.

Arifin, Bambang Samsul, Psikologi Agama, Bandung : Pustaka Setia, 2008.

Boeree, George, Personality Theories, Jokjakarta:Prismasophie, 2008.

Desmita, Psikologi Perkembangan, Bandung: Rosdakarya, 2009.

Erik, H. Erikson, Childhood and Society, Yokyakarta: Pustaka Pelajar, 2010.

Hawi, Akmal, Ilmu Jiwa Agama, Palembang: Katalog Dalam Terbitan , 2005.

Hurlock, Psikologi Perkembangan, Jakarta: Erlangga, 1992.

Kartono, Kartini, Pengantar Metodelogi Riset Sosial, Bandung: Mandar Maju, 1996.

Lia, Papa, Human Development, Jakarta, 2008.

Mohamad, Nazir, Metode Penelitian, Jakarta: Chalia Indonesia, 1988.

Muhamad, Sayyid, Pendidkan Remaja Antara Islam dan Ilmu Jiwa, (Jakarta: Katalog Dalam Terbitan, 2007.

Papalia, Diane E., Human Development, Jakarta : Kencana Pernanda Media Group.

Fajri, Em Zul, Kamus Bahasa Indonesia, Jakarta:Difa Fubliser, 2009.

http://www.you.com/articles/adolescent-agresi. Diunduh pada tanggal 12 Februari 2019, pkl. $16.00 \mathrm{WIB}$

http://www.you.com/articles/adolescent-erk. Diunduh pada tanggal 12 Februari 2019, pkl. $16.00 \mathrm{WIB}$

Sastrok, Jhon W. Perkembangan Anak Edisi 7 Jilid 2. Jakarta: Erlangga, 2011.

Sudarsono, Etika Islam Tentang Kenakalan Remaja, Jakarta: Rineka Cipta, 1989.

Sudarsono, Etika Islam Tentang Kenakalan Remaja, Jakarta: Rineka Cipta, 1989. 
Syamsyu Yusup, Teori Keperibadian, (Bandung: Rosdakarya, 2008) 


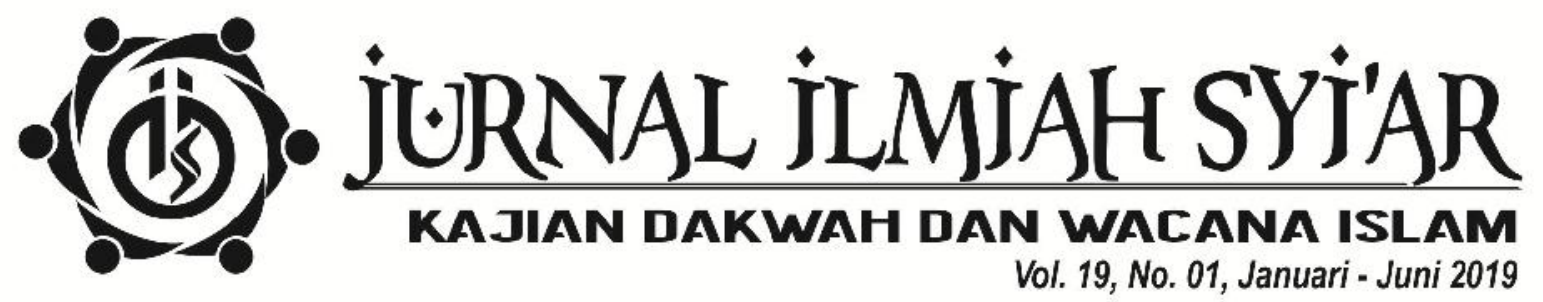




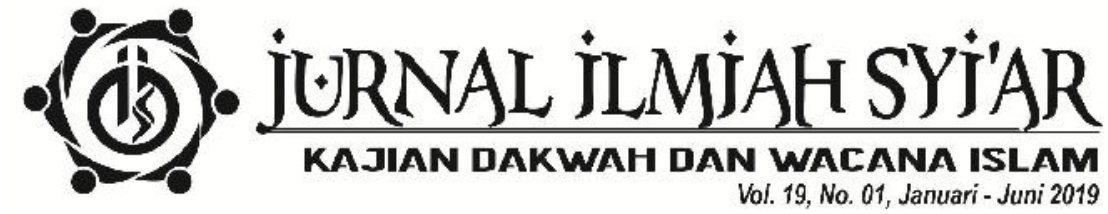

MITRA BESTARI

Khomsyahrial Romli (UIN Raden Intan Lampung)

Nelly Marhayati (IAIN Bengkulu)

Andi Dermawan (UIN Sunan Kalijaga Yogyakarta)

Bayu Mitra Aditya Kusuma (UIN Sunan Kalijaga Yogyakarta)

\section{PENANGGUNG JAWAB}

Suryani

REDAKTUR

Pebri Prandika Putra

EDITOR

Ihsan Rahmat

SEKRETARIS

Haqqi Annazili

DESAIN GRAFIS

Hymawandra

\author{
ALAMAT REDAKSI \\ Fakultas Ushuluddin, Adab, dan Dakwah \\ Institut Agama Islam Negeri Bengkulu \\ Jl. Jalan Raden Patah, Kelurahan, Pagar Dewa, Selebar, Pagar Dewa, Selebar, Kota \\ Bengkulu, Bengkulu 65144, Telp. \\ http:// ejournal.iainbengkulu.ac.id/index.php/syiar
}




\section{PENGANTAR REDAKSI}

Alhamdulillah, Jurnal Ilmiah Syi'ar, Vol. 19, No. 1 telah terbit tepat pada waktunya. Redaksi bersyukur ke hadirat Allah SWT atas seluruh karunia yang telah diberikan, baik yang terlihat ataupun kasat mata. Kemudian, shalawat beserta salam semoga tercurah bagi Nabi Muhammad SAW. Seorang rasul yang mempraktikkan berbagai metode dakwah bagi umat seluruh alam. Pada edisi ini, Jurnal Ilmiah Syi'ar (JIS) mengalami banyak pembenahan dalam rangka menuju akreditasi. Perubahan pertama datang dari ukuran jurnal cetak yang dianggap terlalu besar, sehingga redaksi memutuskan untuk menyesuaikan seukuran buku standar ISBN. Menetapkan waktu terbit dua kali dalam satu tahun, yakni edisi Januari - Juni diterbitkan pada Juni dan Juli - Desember diterbitkan pada Desember. Satu edisi berisi delapan jurnal berkualitas yang dikelola dengan sistem Open Journal System (OJS).

Pada edisi ini juga, redaksi bekerja sama dengan mitra bestari yang dinilai pakar pada salah satu fokus JIS, yaitu Komunikasi dan Penyiaran Islam, Manajemen Dakwah, Pengembangan Masyarakat Islam, Bimbingan Konseling Islam, dan Kesejahteraan Sosial. Selanjutnya, menyediakan logo khusus untuk JIS dengan tujuan mudah dikenali dan profesionalisme. Logo didesain dengan karakter tulisan 'JIS' berbentuk bulat bermakna bahwa Syi'ar Islam diperuntukkan bagi umat seluruh alam. Dakwah tidak membedakan suku, ras, agama, bangsa, dan negara. Kemudian, di luar karakter ada simbol orang yang saling bergandengan bermakna pola baru Syi'ar Islam di masa depan dengan model kolaboratif. Redaksi berpandangan bahwa kompleksitas kehidupan umat tidak mampu lagi diselesaikan dengan cara parsial atau metode dakwah perorangan.

Metode syi'ar Islam tidak mungkin dipisahkan dari sunnah Rasulullah SAW dan Khulafaur Rasyidin. Tulisan pertama mengangkat pembahasan tentang 'Manajemen Baitul Mal pada Masa Khalifah Umar Bin Khathab R.A: Sebuah Tinjauan Sejarah.' Fitmawati sebagai penulis tunggal telah banyak menulusuri proses terbentuknya baitul mal di madinah, sumber dana yang bisa menjadi pemasukan, tata cara pembagian, hingga hal teknis lainnya. Kajian ini ternyata juga mampu menjelaskan sistem ekonomi syariah di masa khalifah kedua. Tulisan kedua berupa pemikiran tentang konseling Islam berjudul 'Konselor dalam Penguatan Nilai dan Moral: Strategi Membentuk Generasi Religius' oleh Muahammad Nikman Nasir. Nasir mempertahankan argumen bahwa di era milenial, konselor membutuhkan nash-nash agama untuk membangun moral klien atau peserta didik. Agama menjadi titik tolak sebagai sumber kekuatan, agama sebagai budaya, dan agama sebagai konteks.

Ashadi Cahyadi mengisi slot ketiga dengan pembahasan 'Pembangunan dan Pemberdayaan Manusia melalui Dana Desa: Pola dari Masa Lalu hingga Sinergitas yang Rancu.' Asumsi studi ini adalah sinergitas infrastruktur diikuti dengan pemberdayaan masyarakat akan menghasilkan 
kesejahteraan yang berkelanjutan. Tetapi temuan mengatakan rasionalitas ini dinilai tidak berjalan bersamaan karena memberikan porsi yang besar untuk infrastruktur dan mengecilkan pemberdayaan manusia. Tulisan keempat milik Sifatul Aliyah dan Bayu Mitra A. Kusuma 'Tuntutan Kinerja dalam Keterancaman Kerja: Dilema Karir Penyuluh Agama Non-Pegawai Negeri Sipil.' Penulis banyak mengeksplor tentang keresahan penyuluh agama, langkah propaganda, hingga kebijaksanaan yang telah dikeluarkan pemerintah. Tulisan kelima berjudul 'Falsafah Huma Betang di Kalimantan Tengah: Sebuah Pergulatan Identitas Konselor Dayak Muslim' oleh Dody Riswanto. Dody menemukan konselor dayak muslim terbentur oleh persepsi negatif dari lingkungan sosial. Kemungkinan latar agama menjadi arus utama yang perlu dipertimbangkan untuk lingkungan Dayak yang rerata menganut agama berbeda. Penyelesaian Falsafah Huma Betang yang mengandung nilai-nilai toleransi dan saling menghargai antar pemeluk agama dinilai sebagai jembatan yang mampu mereduksi persepsi negatif.

Tulisan keenam berjudul 'Sumber Daya Manusia Koperasi Jasa Keuangan Syariah (KJKS) di Kota Padang: Dilema antara Pengelolaan dan Pemahaman Konsep.' M. Zaky Mubarak Lubis dan Netta Agusti menemukan bahwa 39\% pengelola KJKS belum memahami konsep dasar ekonomi Islam. Robeet Thadi menjadi penulis ketujuh dengan pembahasan 'Literasi Media Khalayak di Era Keberlimpahan Infomasi di Media Massa.' Ada pergeseran di era keberlimpahan informasi, yakni dari sulitnya mencari informasi menjadi sulitnya menyaring informasi. Thadi menekankan pentingnya kemampuan literasi media individu untuk melihat dan membedakan dunia nyata dan dunia yang diproduksi oleh media. Tulisan terakhir oleh Sugeng Sejati dengan judul 'Implikasi Egosentris dan Spiritual Remaja dalam Mencapai Perkembangan Identitas Diri.' Temuan utamanya adalah pengembangan identitas remaja yang egosentris dan spiritual ternyata menjadikan remaja tersebut memiliki prinsip dengan peran penting dalam kehidupan dan nilai dalam masyarakat.

Demikian catatan beberapa perubahan jurnal dan cuplikan dari isi JIS Vol. 19, No. 1. Redaksi menyadari bahwa masih terdapat berbagai kekurangan. Sehingga kritikan dan saran yang bersifat membangun sangat diharapkan demi penyempurnaan jurnal ini kedepannya. Akhirnya redaksi mengucapkan banyak terimakasih kepada berbagai pihak yang turut mendukung lahirnya edisi ini. Mulai dari para penulis yang setia merevisi berbagai kekurangan tulisan, para mitra bestari, tim redaksi yang bekerja maksimal, dan lainnya. Redaksi menunggu karya-karya terbaik penulis pada edisi berikutnya. Selamat membaca!!!

Pagar Dewa, Juni 2019 a.n TIM REDAKSI JIS Ihsan Rahmat 


\section{DAFTAR ISI}

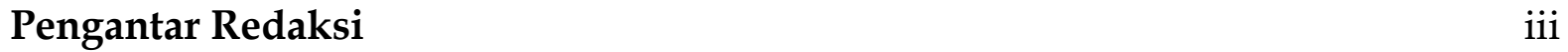

Daftar Isi

MANAJEMEN BAITUL MAL PADA MASA KHALIFAH UMAR BIN 1-29

KHATHAB R.A: SEBUAH TINJAUAN SEJARAH

Fitmawati

KONSELOR DALAM PENGUATAN NILAI DAN MORAL:

$30-42$

STRATEGI MEMBENTUK GENERASI RELIGIUS

Muahammad Nikman Nasir

PEMBANGUNAN DAN PEMBERDAYAAN MANUSIA MELALUI DANA

DESA: POLA DARI MASA LALU HINGGA SINERGITAS YANG RANCU Ashadi Cahyadi

TUNTUTAN KINERJA DALAM KETERANCAMAN KERJA: DILEMA

$55-67$

KARIR PENYULUH AGAMA NON PEGAWAI NEGERI SIPIL

Sifatul Aliyah, Bayu Mitra A. Kusuma

FALSAFAH HUMA BETANG DI KALIMANTAN TENGAH: SEBUAH

$68-76$

PERGULATAN IDENTITAS KONSELOR DAYAK MUSLIM

Dody Riswanto

SUMBER DAYA MANUSIA KOPERASI JASA KEUANGAN SYARIAH

$77-89$

(KJKS) DI KOTA PADANG: DILEMA ANTARA PENGELOLAAN

DAN PEMAHAMAN KONSEP

M. Zaky Mubarak Lubis, Netta Agusti

LITERASI MEDIA KHALAYAK DI ERA KEBERLIMPAHAN INFOMASI DI

90-102

MEDIA MASSA

Robeet Thadi

IMPLIKASI EGOSENTRIS DAN SPIRITUAL REMAJA

103-126

DALAM MENCAPAI PERKEMBANGAN IDENTITAS DIRI

Sugeng Sejati 